\title{
From Bench to Bedside
}

\section{From Bench to Bedside: Targeted Therapy, Denosumab, and 21st Century Orthopaedics: Targets Abound, But Where Are The Therapies?}

\author{
Benjamin K. Potter MD
}

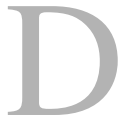

enosumab represents a fully human, monoclonal antibody against receptor activator of

A Note from the Editor-In-Chief:

I am pleased to present the next installment of "From Bench to Bedside," a quarterly column written by Benjamin K. Potter MD.

Dr. Potter is a clinician-scientist in the

Department of Orthopaedics at Walter Reed National Military Medical Center and in the Department of Surgery at the Uniformed Services University of Health Sciences. His column investigates important developments that are making-or are about to make-the transition from the laboratory to clinical practice, as well as technologies and approaches that have recently made that jump.

The institution of one or more of the authors (BKP) has received, during the study period, funding from Congressionally Directed Medical Research Programs.

All ICMJE Conflict of Interest Forms for authors and Clinical Orthopaedics and Related Research ${ }^{\circledR}$ editors and board members are on file with the publication and can be viewed on request.

The opinions expressed are those of the writers, and do not reflect the opinion or policy of $C O R R^{\circledR}$ or The Association of Bone and Joint Surgeons ${ }^{\circledR}$.

The author is an employee of the US

Government and this work was prepared as part of his official duties. As such, there is no copyright to transfer. The views expressed in nuclear factor B (RANK) ligand. In layman's terms — or terms more familiar to orthopaedic surgeons not preparing

this article are those of the author and do not necessarily reflect the official policy or position of the Department of the Army, Department of the Navy, Department of Defense, nor the U.S. Government. I certify that all individuals who qualify as authors have been listed; each has participated in the conception and design of this work, the analysis of data, the writing of the document, and the approval of the submission of this version; that the document represents valid work; that if I used information derived from another source, I obtained all necessary approvals to use it and made appropriate acknowledgements in the document; and that each takes public responsibility for it. Nothing in the presentation implies any Federal/DOA/ DON/DOD endorsement. The author received no financial support for this editorial.

\section{B. K. Potter MD}

Orthopaedic Surgery Service,

Department of Surgery, Uniformed Services University of Health Sciences, Bethesda, MD, USA

B. K. Potter MD ( $\square)$

Walter Reed National Military Medical Center, 8901 Wisconsin Ave., America Building (19), 2nd Floor - Ortho, Bethesda, MD 20889, USA e-mail: Benjamin.k.potter.mil@mail.mil for a recertification exam-denosumab inhibits osteoclasts, mimicking the natural action of osteoprotegerin. Denosumab has been proven to delay or prevent overt or impending fractures requiring treatment in patients with a wide variety of malignancies $[5,6,16]$. It can be used to treat or prevent osteoporosis [12], and is generally considered as effective in these regards as the lategeneration bisphosphonate zoledronic acid. More recently, denosumab has demonstrated efficacy as a standalone or adjuvant therapy in the management of giant cell tumor of bone [2, 3], an aggressive benign tumor that has a proclivity for local recurrence.

Better still, denosumab has, in the past few years, been FDA-approved for the treatment of "unresectable" giant cell tumors [19]. In addition to giving both hope and local inhibition (if not complete control) to patients with this difficult condition, broader clinical use of denosumab in patients with giant cell tumor promises prevention or delay of local recurrence and "downstaging" of surgical disease-making morbid surgery less so and, in some cases, "unresectable" lesions resectable [15]. 
This is fantastic news. Indeed, in this age of increasingly personalized medicine, it seems one cannot open the paper without reading about some fantastic new antibody, drug, or immunotherapy that will "cure" cancer or "change the world" [4, 14].

As physicians and surgeons, we know better. Even denosumab, for all of its promise, has already demonstrated in its brief time on the market that it (like every new therapy) is not a panacea-failing to completely solve issues ranging from giant cell tumor recurrence [11] to atypical femur fractures classically seen following long-term bisphosphonate use [17].

But the promise-and, on some levels, delivery — of denosumab further highlights a more pressing question, namely: Where are the other targeted therapies in orthopaedics? Rotator cuff tears, degenerative disc disease, and osteoarthritis afflict tens of millions of people in the United States alonesurely there must be some agents on the market (or nearly so) to prevent or treat these vexing problems in "targeted" fashion, right? Or not. Numerous targets have been identified to improve rotator cuff tendon healing [13], and a recent investor's guide highlighted 17 candidate drugs from 12 companies for the treatment and prevention of degenerative disc disease [10]. But no therapeutic agents are yet available. Likewise, a recent review identified several targets, new and old, for nonsurgical mitigation of osteoarthritis via so-called disease modifying osteoarthritis drugs and identified the zero drugs available in this hypothetical class [1].

The problem is three-fold-cost, time, and regulations. The Tufts Center for the Study of Drug Development [18] suggests that it costs around USD 2.6 billion and takes more than 10 years to bring a new drug to market. Navigating the FDA-approval process, assuming a candidate drug works, adds additional hurdles and contributes to both the time and expense required. Even the approval of denosumab for treatment of giant cell tumor was granted through a special process (which I applaud) to expedite approval for agents to treat rare or "orphan" conditions. But this sword cuts both ways; osteoarthritis, for example, is not at all rare. The bar is thus much higher for the most common orthopaedic ailments for which such treatments are most needed.

Fortunately, there actually are agents under investigation or "in the pipeline." Unfortunately, none of the agents appear overwhelmingly promising or close to market at this point. So what to do in the meantime? First, participate in trials and assist with recruitment whenever possible; if interested, one need look no further than clinicaltrials.gov and search for active trials (lead investigators are listed, as well) within your personal area of interest or expertise. Next, do not worry-when the first big, targeted therapy for osteoarthritis hits, it will not put orthopaedic surgeons out of business. Most importantly, avoid unproven therapies or, worse still, therapies essentially proven ineffective, such as viscosupplementation, arthroscopic lavage for knee osteoarthritis, or porcine small intestine submucosa augmentation of rotator cuff repairs [7-9]. Last, however, might simply be not to kid ourselves that the era of personalized medicine and targeted therapies has yet arrived.

\section{References}

1. Blanco FJ, Ruiz-Romero C. New targets for disease modifying osteoarthritis drugs: chondrogenesis and Runx1. Ann Rheum Dis. 2013: 72:631-634.

2. Branstetter DG, Nelson SD, Manivel JC, Blay JY, Chawla S, Thomas DM, Jun S, Jacobs I. Denosumab induces tumor reduction and bone formation in patients with giant-cell tumor of bone. Clin Cancer Res. 2012;18: 4415-4424.

3. Chawla S, Henshaw R, Seeger L, Choy E, Blay JY, Ferrari S, Kroep J, Grimer R, Reichardt P, Rutkowski P, Schuetze S, Skubitz K, Staddon A, Thomas D, Qian Y, Jacobs I. Safety 


\section{From Bench to Bedside}

and efficacy of denosumab for adults and skeletally mature adolescents with giant cell tumour of bone: interim analysis of an open-label, parallel-group, phase 2 study. Lancet Onc. 2013;14:901-908.

4. Dreifus C. Arming the immune system against cancer. Available at: http://www.nytimes.com/2015/03/03/ science/arming-the-immune-systemagainst-cancer.html. Accessed February 1, 2016.

5. Fizazi K, Carducci M, Smith M, Damião R, Brown J, Karsh L, Milecki P, Shore N, Rader M, Wang H, Jiang Q, Tadros S, Dansey R, Goessl C. Denosumab versus zolendronic acid for treatment of bone metastases in men with castration-resistant prostate cancer: A randomized, double-blind study. Lancet. 2011;377:813-822.

6. Henry DH, Costa L, Goldwasser F, Hirsh V, Hungria V, Prausova J, Scagliotti GV, Sleeboom H, Spencer A, Vadhan-Raj S, von Moos $R$, Willenbacher W, Woll PJ, Wang J, Jiang Q, Jun S, Dansey R, Yeh H. Randomized, double-blind study of denosumab versus zoledronic acid in the treatment of bone metastases in patients with advanced cancer (excluding breast and prostate cancer) or multiple myeloma. J Clin Onc. 2011;29:1125-1132.

7. Iannotti JP, Codsi MJ, Kwon YW, Derwin K, Ciccone J, Brems JJ. Porcine small intestine submucosa augmentation of surgical repair of chronic twotendon rotator cuff tears. J Bone Joint Surg Am. 2006;88:1238-1244.

8. Kirkley A, Birmingham TB, Litchfield RB, Giffin JR, Willits $\mathrm{KR}$,
Wong CJ, Feagan BG, Donner A, Griffin SH, D'Ascanio LM, Pope JE. A randomized trial of arthroscopic surgery for osteoarthritis of the knee. N Engl J Med. 2008;359:1097-1107.

9. Leopold SS. Editorial: Getting evidence into practice - or not: The case of viscosupplementation. Clin Orthop Rel Res. 2016;474:285-288.

10. Market Research. Degenerative disc disease - pipeline review, H1 2015. Available at: http://www.rnrmarketresearch.com/degenerative-disc-disease-pipeline-review-h1-2015-market-report.html. Accessed January 25, 2016.

11. Matcuk GR Jr, Patel DB, Schein AJ, White EA, Menendez LR. Giant cell tumor: rapid recurrence after cessation of long-term denosumab therapy. Skel Rad. 2015;44:1027-1031.

12. McClung MR, Lewiecki EM, Cohen SB, Bolognese MA, Woodson GC, Moffett AH, Peacock M, Miller PD, Lederman SN, Chesnut CH, Lain D, Kivitz AJ, Holloway DL, Zhang C, Peterson MC, Bekker PJ; AMG 162 Bone Loss Study Group. Denosumab in postmenopausal women with low bone mineral density. $N$ Engl J Med. 2006;354:821-831.

13. Oak NR, Gumucio JP, Flood MD, Saripalli AL, Davis ME, Harning JA, Lynch EB, Roche SM, Bedi A, Mendias CL. Inhibition of 5-LOX, COX-1, and COX-2 increases tendon healing and reduces muscle fibrosis and lipid accumulation after rotator cuff repair. Am J Sports Med. 2014;42:2860-2868.

14. Pollack A. A cell therapy untested in humans saves a baby with cancer.
Available at: http://www.nytimes. com/2015/11/06/business/a-novel-celltherapy-untested-in-humans-savesbaby-with-cancer.html?_r=0. Accessed February 1, 2016.

15. Rutkowski P1, Ferrari S, Grimer RJ, Stalley PD, Dijkstra SP, Pienkowski A, Vaz G, Wunder JS, Seeger LL, Feng A, Roberts ZJ, Bach BA. Surgical downstaging in an open-label phase II trial of denosumab in patients with giant cell tumor of bone. Ann Surg Onc. 2015:22:2860-2868.

16. Stopeck AT, Lipton A, Body JJ, Steger GG, Tonkin K, de Boer RH, Lichinitser M, Fujiwara Y, Yardley DA, Viniegra M, Fan M, Jiang Q, Dansey R, Jun S, Braun A. Denosumab compared with zoledronic acid for treatment of bone metastases in patients with advanced breast cancer: a randomized, double-blind study. J Clin Onc. 2010;28:51325139.

17. Thompson RN, Armstrong CL, Heyburn G. Bilateral atypical femoral fractures in a patient prescribed denosumab - a case report. Bone. 2014;61:44-47.

18. Tufts Center for the Study of Drug Development. Cost to develop and win marketing approval for a new drug is $\$ 2.6$ billion. Available at: http://csdd.tufts.edu/news/complete_ story/pr_tufts_csdd_2014_cost_study. Accessed January 25, 2016.

19. U. S. Food and Drug Administration. FDA approves Xgeva to treat giant cell tumor of the bone. Available at: http:// www.fda.gov/NewsEvents/Newsroom/ PressAnnouncements/ucm356528.htm. Accessed January 25, 2016. 